\title{
Plasma adrenaline and noradrenaline concentrations and dopamine- $\beta$-hydroxylase activity in myocardial infarction with and without cardiogenic shock
}

\author{
CLAUDE R. BENEDICT ${ }^{1}$ AND DAVID G. GRAHAME-SMITH \\ From MRC Unit and University Department of Clinical Pharmacology, Radcliffe Infirmary, \\ Woodstock Road, Oxford
}

SUMMARY In patients with myocardial infarction, with or without cardiogenic shock, plasma noradrenaline and adrenaline concentrations are increased. However, plasma noradrenaline concentrations are considerably higher in patients with cardiogenic shock when compared with those with uncomplicated myocardial infarction. Plasma noradrenaline and adrenaline concentrations showed a sustained increase until death in patients with cardiogenic shock whereas those concentrations were back to normal levels by the end of the third day in patients with uncomplicated myocardial infarction. Plasma dopamine- $\beta$ hydroxylase activities in both the groups were within normal range and did not show any significant variation throughout the period of study.

It has been proposed that plasma noradrenaline and adrenaline concentrations (Von Euler, 1964) and dopamine- $\beta$-hydroxylase $(\mathrm{D} \beta \mathrm{H})$ activities (Axelrod, 1972) may provide information about the function of the sympathetic nervous system and adrenal medulla. Recent technical advances allow these factors to be measured in small volumes of plasma $(0.5 \mathrm{ml})$ and this means that frequent blood sampling can be carried out to monitor dynamic changes in sympathetic nervous system and adrenal medullary function during the course of an illness.

The primary purpose of this study was to determine the changes in plasma noradrenaline and adrenaline concentrations and $\mathrm{D} \beta \mathrm{H}$ activities during an illness in which sympathetic nervous activity is traditionally accepted as being increased, that is cardiogenic shock from myocardial infarction. This necessitated a comparison with uncomplicated cases of myocardial infarction and other 'control' groups of patients. Several studies have already been done showing that urinary excretion of catecholamines (Klein et al., 1968; Hayashi et al., 1969; Jewitt et al., 1969; Prakash et al., 1972) and plasma catecholamine concentrations (Gazes et al., 1959; McDonald et al., 1969; Griffiths and Leung, 1971; Januszewicz et al., 1971; Siggers et al., 1971; Lukomsky and Oganov, 1972; Videbaek et al., 1972) are raised in the acute phase of myocardial 1 Rhodes Scholar.

Received for publication 22 December 1978 infarction. A secondary purpose was to see whether there was any relation between plasma noradrenaline and adrenaline concentrations and the severity of the myocardial infarction and its circulatory effects.

\section{Patients and methods}

\section{PATIENTS}

Patients who were admitted to the coronary care unit with myocardial infarction with or without cardiogenic shock were investigated.

\section{(1) Patients with cardiogenic shock after myocardial} infarction

The definitition of cardiogenic shock was as follows: systolic blood pressure less than $90 \mathrm{mmHg}$ or $30 \mathrm{mmHg}$ less than the systolic pressure before admission; peripheral cyanosis with cold clammy extremities and oliguria of less than $20 \mathrm{ml} / \mathrm{h}$. Tachycardia and altered level of consciousness were not included because patients in cardiogenic shock often have a slow pulse caused by sinus bradycardia or conduction defects and remain mentally alert. Eleven men and one woman aged $59 \cdot 2 \pm 3 \cdot 7$ years (mean $\pm \mathrm{SEM}$ ) were included in this group.

(2) Patients with myocardial infarction without cardiogenic shock

All the patients had a typical history with welldefined onset, electrocardiographic changes diagnostic of acute myocardial infarction, and raised lactic 
dehydrogenase (LDH) (cardiospecific fraction) over $600 \mathrm{IU} / \mathrm{ml}$. Six male and 2 female patients aged $59 \cdot 10 \pm 3.9$ years were included in this group.

Previous studies indicated that the occurrence of cardiac arrhythmias in these patients is associated with high plasma catecholamine concentrations (Jewitt et al., 1969; McDonald et al., 1969; Griffiths and Leung, 1971; Siggers et al., 1971). Since the aim of the study was to investigate the relation between plasma adrenaline and noradrenaline concentrations and $\mathrm{D} \beta \mathrm{H}$ activities and clinical evidence of shock, cases with more than transient arrhythmias were excluded. Patients who received isoprenaline or noradrenaline were not included as these drugs interfere with the assay for plasma adrenaline and noradrenaline. Patients who received any beta-blocking drugs during the week before admission or after admission were excluded because these drugs may alter plasma catecholamine concentrations (Brecht et al., 1976; Rahn et al., 1976). Venous blood samples, $5 \mathrm{ml}$, were collected on admission, after 30 minutes of supine rest and then at 4-hourly intervals for the first 12 hours, at 6-hourly intervals for the next 36 hours, and then at 8-hourly intervals for the rest of the period of study.

In all patients the following factors were monitored. Hourly measurement of (i) blood pressure, (ii) pulse rate, (iii) urinary output (in patients with cardiogenic shock indwelling catheters were used); 24-hour monitoring for cardiac arrhythmias; daily chest $x$-ray film, and frequent clinical examination for the detection of pulmonary oedema; daily measurement of LDH (cardiospecific fraction). None of the patients in the 2 groups received any drugs other than the following: diamorphine, oxygen by facial mask, 5 per cent dextrose intravenous drip with or without lignocaine, frusemide intravenously or orally, and either nitrazepam or diazepam.

All the patients with myocardial infarction without complications were transferred to a general ward after 3 to 4 days' stay in the coronary care unit and all eventually went home. Of the 12 patients with cardiogenic shock, 11 died 6 to 48 hours after admission to the coronary care unit.

'CONTROL' GROUP OF PATIENTS

The third and fourth groups of patients consisted of age and sex matched controls.

(3) Patients admitted for cardiac catheterisation

Six patients ( 3 men and 3 women aged 42.0 $\pm 2 \cdot 7$ years) with congenital heart disease who were normotensive, not in congestive cardiac failure, and not taking any drugs were included in this group. A venous blood sample was collected after 30
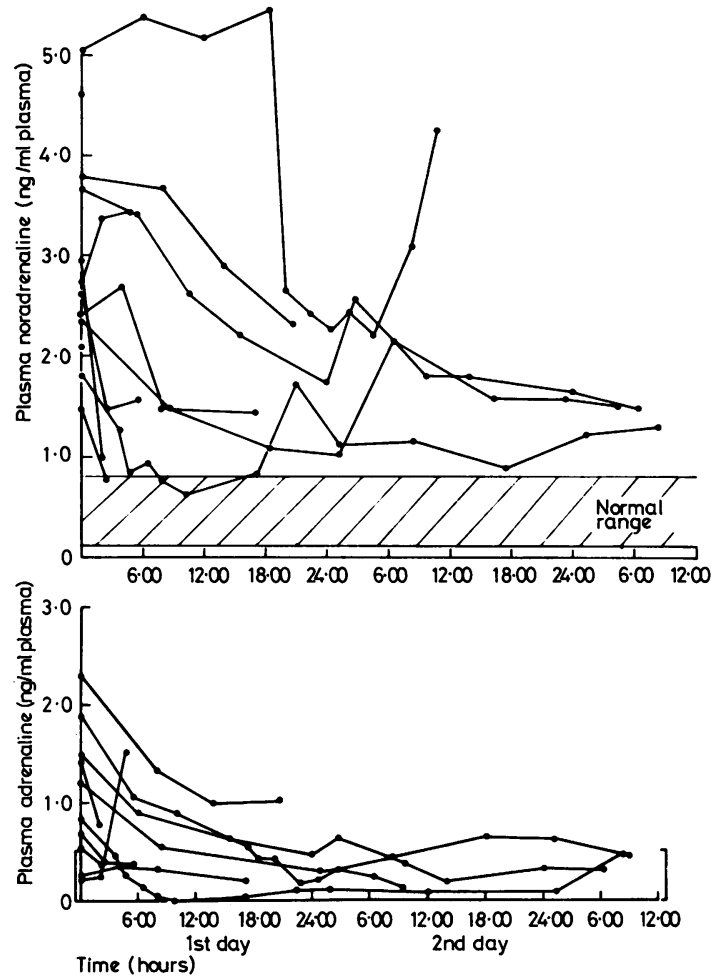

Fig. 1 Serial estimation of plasma noradrenaline (above) and adrenaline (below) in cardiogenic shock. For conversion to $S I$ units: adrenaline, $1 \mathrm{ng} / \mathrm{ml} \approx 5.458$ nmol $/ \mathrm{l}$; noradrenaline, $1 \mathrm{ng} / \mathrm{ml} \approx 5.9101 \mathrm{nmol} / \mathrm{l}$.

minutes of bed rest at the time of admission, at 12,24 , and 48 hours after admission and, finally, before discharge. The cardiac catheterisation was performed 14 to 18 hours after admission and all patients received pethidine 50 to $100 \mathrm{mg}$ intramuscularly before the procedure.

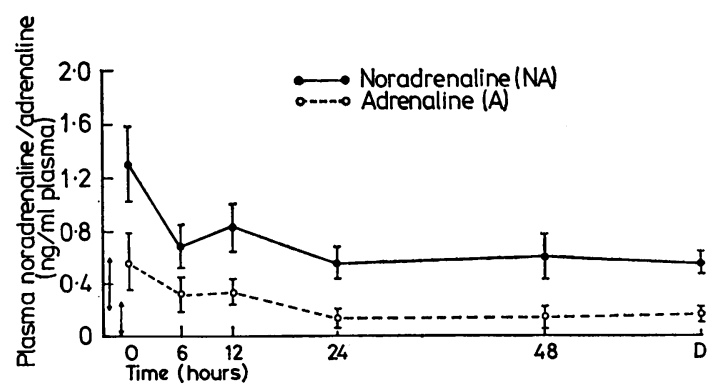

Fig. 2 Serial estimation of plasma noradrenaline (above) and adrenaline (below) in myocardial infarction without complication. For conversion to SI units: adrenaline, $1 \mathrm{ng} / \mathrm{ml} \approx 5.458 \mathrm{nmol} / \mathrm{l}$; noradrenaline, $1 \mathrm{ng} / \mathrm{ml} \approx$ $5.9101 \mathrm{nmol} / \mathrm{l}$. 


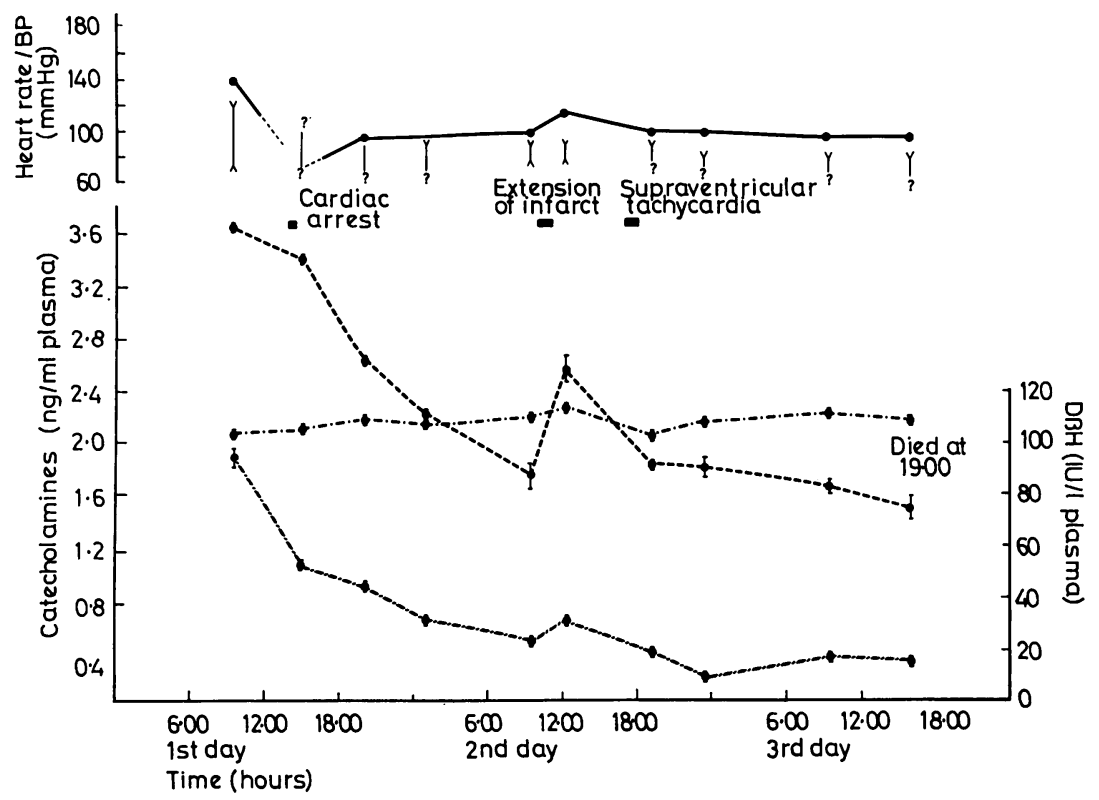

Fig. 3 Sequential measurement of plasma noradrenaline (-----), adrenaline (-1-1-1-1-), and dopamine- $\beta$-hydroxylase $(-\cdot---)$, and blood pressure $(Y)$, and heart rate (-) in a patient with cardiogenic shock. For conversion to SI units: adrenaline, $1 \mathrm{ng} / \mathrm{ml} \approx$ $5.458 \mathrm{nmol} / \mathrm{l}$; noradrenaline, $1 \mathrm{ng} / \mathrm{ml} \approx 5.9101 \mathrm{nmol} / \mathrm{l}$.
(4) Patients admitted with other disease

Ten patients ( 5 men and 5 women aged 42.5 $\pm 5 \cdot 5$ years) admitted with the following acute illnesses were included in this group: (1) lobar pneumonia, (2), (3), and (4) acute appendicitis, (5) systemic lupus erythematosus with fever and impairment of the renal function, (6) urinary tract infection, (7) pleurisy, (8) acute cholecystitis, (9) renal colic, (10) acute pericarditis. Venous blood samples were collected after 30 minutes of bed rest from all these patients within 2 hours of admission and then daily for 5 days by which time their acute symptoms were subsiding. None of these patients was clinically hypovolaemic or hypotensive and none had septicaemia.

Plasma adrenaline and noradrenaline concentrations were measured by a radioenzymatic method (Hörtnagl et al., 1977) while D $\beta H$ activity was measured by a photometric method (Nagatsu and Udenfriend, 1972). The normal range for plasma LDH activity was 240 to $525 \mathrm{IU} / \mathrm{ml}$. The data, expressed as mean \pm SEM, were analysed using Student's unpaired t test (2-tailed).

\section{Results}

(1) PLASMA ADRENALINE AND NORADRENALINE CONCENTRATIONS AND $D \beta H$ ACTIVITIES

(a) Patients with cardiogenic shock

These patients were admitted with cardiogenic shock or developed it within 6 hours of admission.

In these patients plasma noradrenaline concen- trations at the time of admission, $17 \cdot 4 \pm 1.9$ $\mathrm{nmol} / \mathrm{l}(2.94 \pm 0.32 \mathrm{ng} / \mathrm{ml})$ (Fig. 1) were greater than the corresponding concentrations for patients with uncomplicated myocardial infarction, $7.7 \pm$ $1.7 \mathrm{nmol} / 1(1.30 \pm 0.28 \mathrm{ng} / \mathrm{ml})$ (Fig. 2) $(P<0.005)$,

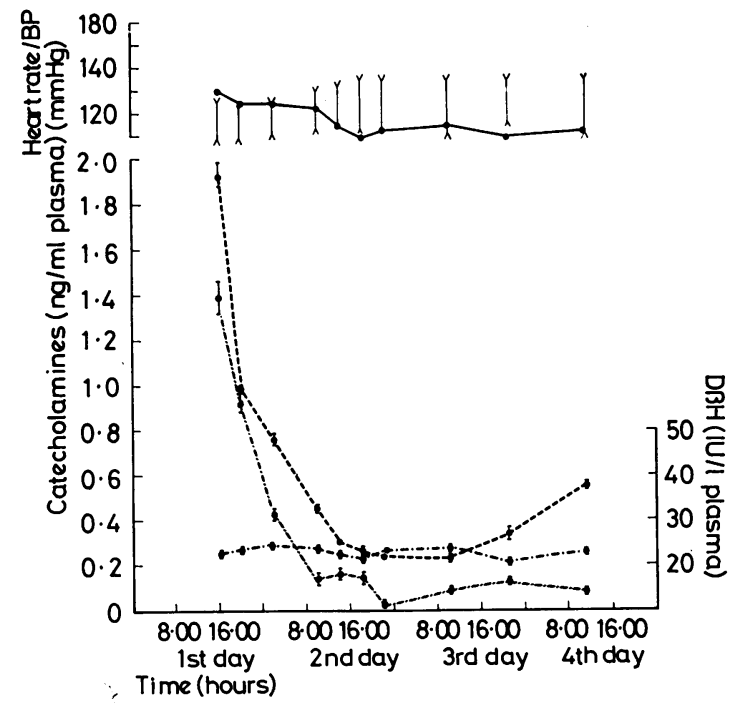

Fig. 4 Sequential measurement of plasma noradrenaline (-----), adrenaline (-I-I-I-I-), and dopamine- $\beta$ hydroxylase (-----), and blood pressure ( $(\chi)$, and heart rate (-) in a patient with uncomplicated myocardial infarction. For conversion to SI units: adrenaline $1 \mathrm{ng} / \mathrm{ml} \approx 5.458 \mathrm{nmol} / \mathrm{l}$; noradrenaline, $1 \mathrm{ng} / \mathrm{ml} \approx 5.9101 \mathrm{nmol} / \mathrm{l}$. 


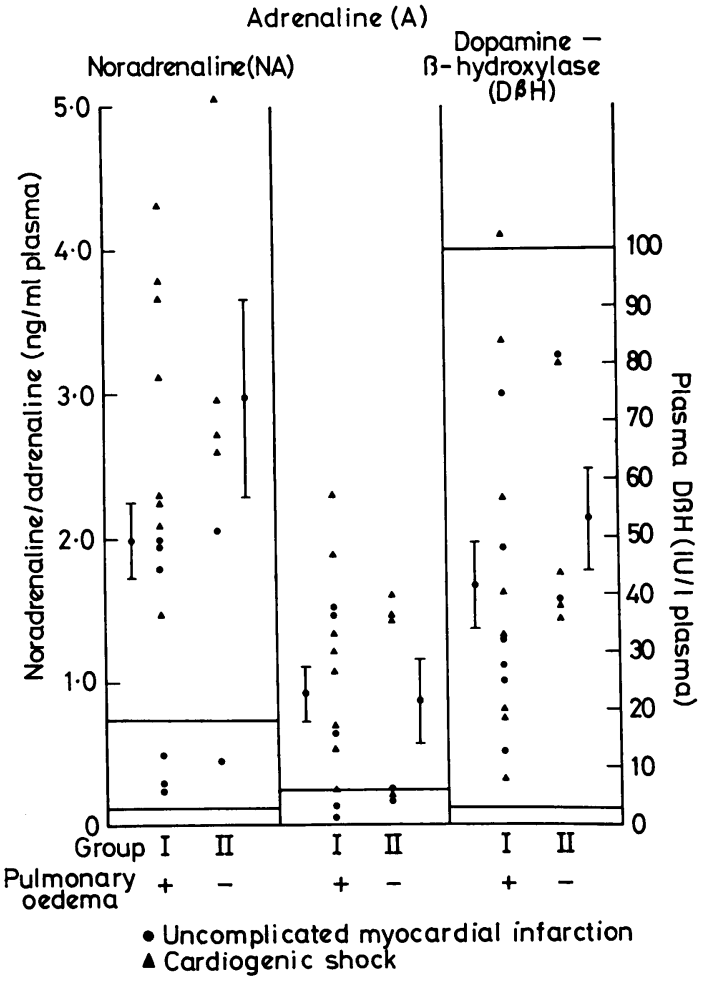

Fig. 5 Comparison of the admission values of noradrenaline $(N A)$, adrenaline $(A)$, and dopamine- $\beta$ hydroxylase $(D \beta H)$ (mean $\pm S E M)$ in patients who had pulmonary oedema on admission with that of patients without it on admission. For conversion to $S I$ units : adrenaline, $1 \mathrm{ng} / \mathrm{ml} \approx 5.458 \mathrm{nmol} / \mathrm{l}$. Nonadrenaline $1 \mathrm{ng} / \mathrm{ml} \approx 5.910 \mathrm{nmol} / \mathrm{l}$.

patients admitted for catheterisation, $1.7 \pm 0.06$ $\mathrm{nmol} / 1(0.29 \pm 0.02 \mathrm{ng} / \mathrm{ml}) \mathrm{P}<0.001)$, and patients with various diseases $2.7 \pm 0.4 \mathrm{nmol} / 1 \quad(0.46 \pm$ $0.06 \mathrm{ng} / \mathrm{ml})(\mathrm{P}<0.001)$ (Table 1). Though these increased noradrenaline concentrations declined slightly with time, the concentrations measured 1 to 4 hours before the death of the patients, $11 \cdot 2 \pm$ $2.1 \mathrm{nmol} / 1 \quad(1.89 \pm 0.35 \mathrm{ng} / \mathrm{ml})$ remained higher than the noradrenaline concentrations measured in patients with uncomplicated myocardial infarction when they were admitted to the coronary care unit $(\mathbf{P}<0.05)$.

The plasma adrenaline concentrations in patients with cardiogenic shock at the time of admission were $6 \cdot 17 \pm 1.04 \mathrm{nmol} / 1(1 \cdot 13 \pm 0 \cdot 19 \mathrm{ng} / \mathrm{ml})$ (Fig. 1) which were not significantly different from the adrenaline concentrations measured in patients with uncomplicated myocardial infarction, $3 \cdot 11 \pm$ $1.15 \mathrm{nmol} / \mathrm{l}(0.57 \pm 0.21 \mathrm{ng} / \mathrm{ml}$ ) (Fig. 2), but were significantly greater than the corresponding values for patients admitted for cardiac catheterisation,
$0.76 \pm 0.22 \mathrm{nmol} / 1 \quad(0.14 \pm 0.04 \mathrm{ng} / \mathrm{ml}),(P<0.005)$, and patients admitted with various disorders, $3.17 \pm 0.49 \mathrm{nmol} / 1 \quad(0.58 \pm 0.09 \mathrm{ng} / \mathrm{ml}) \quad(P<0.05)$ (Table). Though the plasma adrenaline concentrations declined in patients with cardiogenic shock the concentrations measured 1 to 4 hours before the death of the patient, $2 \cdot 78 \pm 0.76 \mathrm{nmol} / 1$ $(0.51 \pm 0.14 \mathrm{ng} / \mathrm{ml})$ were still considerably above the normal range.

The plasma $\mathrm{D} \beta \mathrm{H}$ activities measured in patients with cardiogenic shock on admission $(46 \cdot 7 \pm 3 \cdot 8 \mathrm{IU} /$ 1) were not significantly different from the corresponding values in patients with uncomplicated myocardial infarction $(42.6 \pm 8.6 \mathrm{IU} / \mathrm{l})$ or the 2 'control' groups of patients (Table).

An example of a patient with cardiogenic shock who was investigated is given below (Fig. 3).

Case 1: A 73-year-old man with a past history of ischaemic heart disease was admitted to the coronary care unit with anterior myocardial infarct. On admission he was shocked and had a blood pressure of $90 / 55 \mathrm{mmHg}$, with a sinus tachycardia of $136 / \mathrm{min}$, and was in pulmonary oedema with pale cold extremities. Soon after admission the patient arrested and he was resuscitated, but only his systolic blood pressure was recordable. On the second day of his stay in the coronary care unit he had an extension of his myocardial infarct followed by a 10-minute episode of supraventricular tachycardia. The patient died on the third day after admission and necropsy showed a fresh anterolateral infarct.

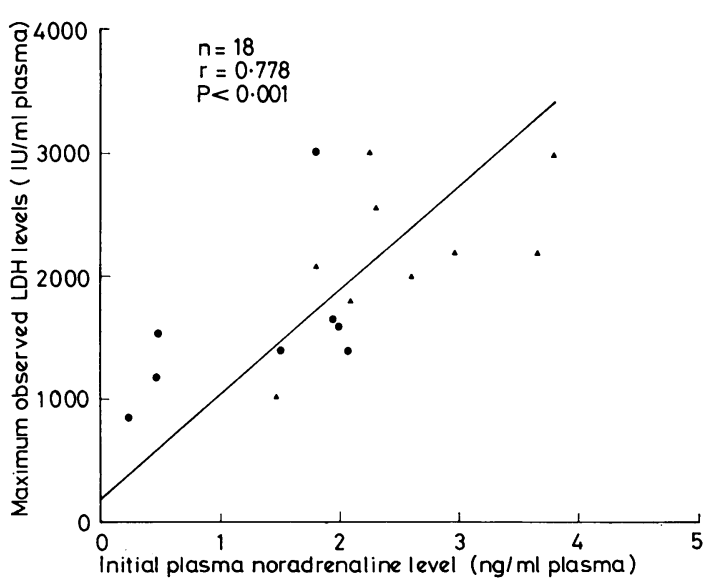

Fig. 6 Correlation of maximum observed LDH levels (cardiospecific fraction) with plasma noradrenaline levels observed at the time of admission (O-myocardial infarction; $\Delta$ cardiogenic shock). For conversion to $S I$ units : adrenaline, $1 \mathrm{ng} / \mathrm{ml} \approx 5.458 \mathrm{nmol} / \mathrm{l}$; noradrenaline, $1 \mathrm{ng} / \mathrm{ml} \approx 5.9101 \mathrm{nmol} / \mathrm{l}$. 
(b) Patients with myocardial infarction without complications

The plasma noradrenaline concentrations present in patients with uncomplicated myocardial infarction at the time of admission, $7.7 \pm 1.7 \mathrm{nmol} / 1$ $(1.30 \pm 0.28 \mathrm{ng} / \mathrm{ml}$ ) (Fig. 2), were significantly greater than the corresponding values for the patients admitted for cardiac catheterisation, $1.7 \pm$ $0.1 \mathrm{nmol} / 1(0.29 \pm 0.02 \mathrm{ng} / \mathrm{ml}),(\mathrm{P}<0.01)$ and the values for patients admitted with various other diseases, $2.7 \pm 0.4 \mathrm{nmol} / 1(0.46 \pm 0.06 \mathrm{ng} / \mathrm{ml}),(P<$ 0.02 ) (Table). The increased noradrenaline concentrations gradually declined after admission and within 48 to 72 hours after admission to the unit the concentrations were similar to normal values in healthy subjects.

The plasma adrenaline concentrations in patients with uncomplicated myocardial infarction were increased at the time of admission, $3 \cdot 11 \pm 1 \cdot 15$ $\mathrm{nmol} / 1 \quad(0.57 \pm 0.21 \mathrm{ng} / \mathrm{ml})$ (Fig. 2). They were not significantly different from the corresponding concentrations of adrenaline measured in patients with various other diseases, $3.17 \pm 0.49 \mathrm{nmol} / 1$ $(0.58 \pm 0.09 \mathrm{ng} / \mathrm{ml})$ or from those measured in patients admitted for cardiac catheterisation, $0.76 \pm$ $0.23 \mathrm{nmol} / 1 \quad(0.14 \pm 0.04 \mathrm{ng} / \mathrm{ml})$ (Table). The increased plasma adrenaline concentrations in patients with uncomplicated myocardial infarction returned to normal within 24 hours of admission.

An example of a patient with uncomplicated myocardial infarction who was investigated is given below.

Case 2 (Fig. 4): A 39-year-old man with a past history of myocardial infarction was admitted to the coronary care unit with an acute anteroinferior myocardial infarct. On admission he had a blood pressure of $105 / 70 \mathrm{mmHg}$ and a pulse rate of $80 /$ min. He was pale and sweating profusely but did not have pulmonary oedema. His hospital course was uncomplicated and he was discharged on the 11 th day after admission.

(c) Patients admitted for cardiac catheterisation

The plasma noradrenaline and adrenaline concentrations and $\mathrm{D} \beta \mathrm{H}$ activities measured in these patients are given in the Table. Plasma adrenaline and noradrenaline concentrations and $\mathrm{D} \beta \mathrm{H}$ acjivities in this group of patients were within normal range. There were no significant changes in any of these measurements before and immediately after catheterisation.

\section{(d) Patients admitted with 'various diseases'}

The plasma noradrenaline and adrenaline concentrations and $\mathrm{D} \beta \mathrm{H}$ activities measured in these patients are given in the Table. Though in these patients the plasma noradrenaline concentrations and $\mathrm{D} \beta \mathrm{H}$ activities were not increased at the time of admission the plasma adrenaline concentrations were increased. The increased plasma adrenaline concentrations returned to normal with 2 to 3 days of admission to hospital.

(2) CORRELATION BETWEEN PRESENCE OR ABSENCE OF PULMONARY OEDEMA AND PLASMA NORADRENALINE AND ADRENALINE CONCENTRATIONS AND D $\beta$ H ACTIVITIES AT TIME OF ADMISSION

All the patients with myocardial infarction, whether in cardiogenic shock or not, were divided into 2 groups, those who had pulmonary oedema detectable clinically and radiologically at the time

Table Plasma adrenaline (A), noradrenaline (NA), and dopamine- $\beta$-hydroxylase (D $\beta H)$ concentrations in 'control' patients (mean $\pm S E M)$

\begin{tabular}{|c|c|c|c|c|c|c|}
\hline & & On admission & 12 hours & 24 hours & 48 hours & $\begin{array}{l}\text { At the time } \\
\text { of discharge }\end{array}$ \\
\hline \multirow{3}{*}{$\begin{array}{l}\text { Cardiac } \\
\text { catheterisation } \\
\text { group }\end{array}$} & $\mathrm{A} \quad(\mathrm{ng} / \mathrm{ml})^{\star}$ & $0.14 \pm 0.04$ & $0.17 \pm 0.05$ & $0.18 \pm 0.04$ & $0.16 \pm 0.05$ & $0.15 \pm 0.03$ \\
\hline & $\mathrm{NA}(\mathrm{ng} / \mathrm{ml}) \dagger$ & $0.29 \pm 0.02$ & $0.28 \pm 0.02$ & $0.29 \pm 0.03$ & $0.30 \pm 0.03$ & $0.30 \pm 0.02$ \\
\hline & $\mathrm{D} \beta \mathrm{H} \quad(\mathrm{IU} / \mathrm{l})$ & $39 \cdot 18 \pm 2 \cdot 34$ & $39 \cdot 27 \pm 2 \cdot 15$ & $39 \cdot 52 \pm 2.08$ & $37 \cdot 83 \pm 2 \cdot 1$ & $38 \cdot 97 \pm 2 \cdot 14$ \\
\hline & & On admission & 24 hours & 48 hours & 72 hours & 96 hours \\
\hline \multirow{3}{*}{$\begin{array}{l}\text { Various } \\
\text { disease } \\
\text { group }\end{array}$} & $A \quad(\mathrm{ng} / \mathrm{ml})$ & $0.58 \pm 0.09$ & $0.55 \pm 0.06$ & $0.33 \pm 0.04$ & $0.16 \pm 0.06$ & $0.17 \pm 0.05$ \\
\hline & $\mathrm{NA}(\mathrm{ng} / \mathrm{ml})$ & $0.46 \pm 0.06$ & $0.45 \pm 0.05$ & $0.48 \pm 0.03$ & $0.42 \pm 0.03$ & $0.40 \pm 0.06$ \\
\hline & $\mathrm{D} \beta \mathrm{H}(\mathrm{IU} / \mathrm{l})$ & $50 \cdot 26 \pm 2 \cdot 86$ & $52 \cdot 71 \pm 2 \cdot 45$ & $50 \cdot 56 \pm 2.32$ & $48 \cdot 64 \pm 2 \cdot 36$ & $47 \cdot 46 \pm 2 \cdot 38$ \\
\hline
\end{tabular}

The normal range for this laboratory (Hörtnagl et al., 1977)

A $\quad=<0.02-0.26 \mathrm{ng} / \mathrm{ml}$

$\mathrm{NA}=0.23-0.72 \mathrm{ng} / \mathrm{ml}\} \mathrm{n}=16$

$\mathrm{D} \beta \mathrm{H}=2 \cdot 2-88.6 \mathrm{IU} / 1$

$\star$ For conversion to SI units $1 \mathrm{ng} / \mathrm{ml} \approx 5.458 \mathrm{nmol} / 1$.

+ For conversion to $S I$ units $1 \mathrm{ng} / \mathrm{ml} \approx 5.9101 \mathrm{nmol} / 1$. 
of admission and those who did not. The plasma noradrenaline and adrenaline concentrations and $D \beta H$ activities measured in those 2 groups of patients are given in Fig. 5 and are not significantly different.

(3) RELATION BETWEEN PEAK CARDIOSPECIFIC LDH CONCENTRATIONS AND PLASMA

NORADRENALINE AND ADRENALINE CONCENTRATIONS AND D $\beta$ H ACTIVITIES MEASURED AT TIME OF ADMISSION

The maximum cardiospecific LDH concentration (found at 3 to 5 days after the infarct) measured in patients with myocardial infarction (including those with cardiogenic shock) was plotted against the plasma noradrenaline concentrations present at the time of admission (Fig. 6). There was a significant correlation between the 2 variables $(r=0.778$; $\mathbf{P}<0.001)$. However, there was no correlation between either plasma adrenaline concentrations or $\mathrm{D} \beta \mathrm{H}$ activity and the maximum cardiospecific $\mathrm{LDH}$ concentrations.

\section{Discussion}

The present study differs from other studies in this field in that plasma adrenaline and noradrenaline concentrations were measured at frequent intervals by a sensitive radioenzymatic method at the same time as $\mathrm{D} \beta \mathrm{H}$ activity estimation.

When patients who were not acutely ill were admitted to hospital plasma noradrenaline and adrenaline concentrations and $D \beta H$ activities did not change significantly (cardiac catheterisation group). This supports the finding of $\mathrm{McDonald}$ et al. (1969) that the stress of admission to hospital and of investigation does not alter plasma catecholamine concentrations.

Plasma noradrenaline concentrations are raised in patients with myocardial infarction and are considerably raised in patients with cardiogenic shock. Plasma noradrenaline concentrations in both the 'control' groups were within the normal range.

There was a significant correlation between plasma noradrenaline concentrations and maximum observed cardiospecific LDH activities which is a crude index of infarct size (Killen and Tinsley, 1966). A similar relation between urinary excretion of noradrenaline and cardiospecific LDH activities has been noted. It is possible that the bigger the size of the myocardial infarct the greater is the extent of sympathetic stimulation, which may explain the correlation between plasma noradrenaline concentration and LDH activity.

McDonald et al. (1969) found a significant correlation between the presence of pulmonary oedema and increased plasma catecholamine concentrations. We did not find any such correlation, confirming the findings of Siggers et al. (1971) who found no correlation between peak values of plasma adrenaline or noradrenaline concentrations and presence of pulmonary oedema. The absence of pulmonary oedema in our patients, particularly those with cardiogenic shock, possibly could be the result of infarction involving the right as well as the left ventricle or could simply be because the number of patients studied was small.

When patients with uncomplicated myocardial infarction or with 'various diseases' were admitted their plasma adrenaline concentrations were signicantly higher than those of patients admitted for catheter studies and returned to normal within 3 to 4 days. In contrast, in patients with cardiogenic shock there was an even greater increase in plasma adrenaline concentrations which remained raised until they died. This suggests that in patients with acute illness there is increased adrenal medullary function which rapidly returns towards normal as the patient recovers, while in those with cardiogenic shock the activity of the adrenal medulla remains high.

There was no significant difference in plasma $\mathrm{D} \beta \mathrm{H}$ activities among the 4 groups and sequential changes in all the groups were not significantly different. Gutteberg et al. (1976) reported that $\mathrm{D} \beta \mathrm{H}$ activities found during the first 2 days after myocardial infarction were significantly different from the $\mathrm{D} \beta \mathrm{H}$ activities present 10 days after infarction. We did not, however, follow our patients up to 10 days. It is evident from our study that measurement of plasma $D \beta H$ activities is not a useful index of sympathetic nervous system function when compared with determinations of plasma noradrenaline concentrations.

Although rises in plasma noradrenaline and adrenaline might be accounted for by several processes, that is increased release and decreased removal by re-uptake and metabolism, it seems very likely, taking into account the clinical picture, that sympathetic nervous system and adrenal medullary function are increased in myocardial infarction and if cardiogenic shock ensues the increased activity is even more obvious.

\section{References}

Axelrod, J. (1972). Dopamine-beta-hydroxylase: regulation of its synthesis and release from nerve terminals. Pharmocological Reviews, 24, 233-243.

Brecht, H. M., Banthien, F., and Schoeppe, W. (1976). Decrease in plasma noradrenaline levels following longterm treatment with prindolol in patients with essential hypertension. Klinische Wochenschrift, 54, 1095-1106.

Gazes, P. C., Richardson, J. A., and Woods, E. F. (1959). 
Plasma catecholamine concentrations in myocardial infarction and angina pectoris. Circulation, 19, 657-661.

Griffiths, J., and Leung, F. (1971). The sequential estimation of plasma catecholamines and blood histamine in myocardial infarction. American Heart fournal, 82, 171-179.

Gutteberg, T., Borud, O., and Stromme, J. H. (1976). Dopamine-beta-hydroxylase activity in serum following acute myocardial infarction: an evaluation of this parameter for routine use as an index of sympathetic activity. Clinica Chimica Acta, 69, 61-66.

Hayashi, K. D., Moss, A. J., and Yu, P. N. (1969). Urinary catecholamine excretion in myocardial infarction. Circulation, 40, 473-481.

Hörtnagl, H., Benedict, C. R., Grahame-Smith, D. C., and McGrath, B. (1977). A sensitive radioenzymatic assay for adrenaline and noradrenaline in plasma. British fournal of Clinical Pharmacology, 4, 553-558.

Januszewicz, W., Sznajderman, M., Ciswicka-Sznajderman, M., Wocial, B., and Rymaszewski, Z. (1971). Plasma free fatty acid and catecholamine levels in patients with acute myocardial infarction. British Heart fournal, 33, 716-718.

Jewitt, D. E., Reid, D., Thomas, M., Mercer, C. J., Valeri, C., and Shillingford, J. P. (1969). Free noradrenaline and adrenaline excretion in relation to the development of cardiac arrhythmias and heart failure in patients with acute myocardial infarction. Lancet, 1, 635-641.

Killen, D. A., and Tinsley, E. A. (1966). Serum enzymes in experimental myocardial infarcts. Archives of Surgery, 92, 418-422.

Klein, R. F., Troyer, W. G., Thompson, H. K., Bogdonoff, M. D., and Wallace, A. G. (1968). Catecholamine excretion in myocardial infarction. Archives of Internal Medicine, 122, 476-482.

Lukomsky, P. E., and Oganov, R. G. (1972). Blood plasma catecholamines and their urinary excretion in patients with acute myocardial infarction. American Heart fournal, 83, 182-188.

McDonald, L., Baker, C., Bray, C., McDonald, A., and Restieaux, N. (1969). Plasma catecholamines after cardiac infarction. Lancet, 2, 1021-1023.

Nagatsu, T., and Udenfriend, S. (1972). Photometric assay of dopamine- $\beta$-hydroxylase activity in human blood. Clinical Chemistry, 18, 980-983.

Prakash, R., Parmley, W. W., Horvat, M., and Swan, H. J. C. (1972). Serum cortisol plasma free fatty acids and urinary catecholamines as indicators of complications in acute myocardial infarction. Circulation, 45, 736-745.

Rahn, K. H., Gierlichs, H. W., Planz, G., Planz, R., and Stephany, W. (1976). Effect of propranolol on plasma catecholamines in hypertensive patients (abstract). In European Society for Clinical Investigation, 10th Annual Meeting, Rotterdam, Netherlands, 22-24 April, p. 13.

Siggers, D. C., Salter, C., and Fluck, D. C. (1971). Serial plasma adrenaline and noradrenaline levels in myocardial infarction using a new double isotope technique. British Heart fournal, 33, 878-883.

Videbaek, J., Christensen, N. J., and Sterndorff, H. (1972). Serial determination of plasma catecholamines in myocardial infarction. Circulation, 46, 846-855.

Von Euler, U. S. (1964). Quantitation of stress by catecholamine analysis. Clinical Pharmacology and Therapeutics, 5, 398-404.

Requests for reprints to Dr C. R. Benedict, Department of Medicine, The Johns Hopkins School of Medicine, The Johns Hopkins Hospital, Baltimore, Maryland 21206, USA. 